\title{
CONVERGENCE AND DIVERGENCE BETWEEN THE EUROPEAN DIRECTIVES AND EUROPEAN COUNTRIES FINANCIAL AUDIT LEGISLATION: EVIDENCE FROM ROMANIA AND REPUBLIC OF MOLDOVA
}

\author{
Tatiana Dănescu ${ }^{l}$ \\ Maria-Alexandra Popa ${ }^{2}$ \\ Mariana Vasileva ${ }^{3}$
}

\begin{abstract}
Financial audit, by its object, is a mean of helping to stabilize the economy at national and international level, and a special concern is given to professional bodies, national and European authorities in developing regulations to improve, facilitate and, in at the same time, to standardize financial audit procedures. Each European country adopts laws, codes, ordinances, and practices that aim to comply with European standards. Drawing from this consideration, we conducted research on the basis of analyzing and comparing the financial audit legislation of two countries in the European geographical area, one member of the European Union (Romania) and one outside the EU area (Republic of Moldova), but with aspirations for integration in the European Union. The objective of this research is to identify and to analyze the convergences and divergences between the norms found in the two states in accordance with European directives.
\end{abstract}

Keywords: External Audit, Regulation, European Directives, International Standards Of Audit, Auditing, Government Policy and Regulation

JEL Classification: K220, M420, M480

\section{Introduction}

Over the years, the financial audit has intended controversial discussions, its implementation being analyzed during economic development in an international context.

The information submitted by the financial information users' entities has an important role to play in making their management decisions. In this respect, it is noted that the need to be informed becomes more rigorous each day, with the development of the world economy towards aggregation of markets and competition. This phenomenon significantly influences financial information, becoming a key element in the harmonious development of a business. Therefore, the main actor in overseeing the financial information reported by the entities is the financial auditor, who'd role is to ensure that the financial information presented by the entity is consistent with a reporting financial framework.

The following normative acts are also intended to regulate the legal framework for the implementation of financial audit activity and the exercise of the profession in the field of auditing, fulfilling all requirements of professional ethics and professional scepticism that the International Standards on Auditing, together with other regulations, require to comply.

At EU level, audit activity is regulated by Directive 2006/43/EC, as amended by the European Directive 2014/56/EU.

\footnotetext{
${ }^{1}$ PhD., Petru Maior University of Tîrgu Mureș, Romania, Email:tatiana.danescu@ gmail.com

${ }^{2}$ PhD. Student, “1 Decembrie 1918” University of Alba Iulia, Romania, Email:vasilevamariana575@yahoo.com

${ }^{3} \mathrm{PhD}$. Student, “1 Decembrie 1918” University of Alba Iulia, Romania, Email:alexandra.popa@hotmail.com

DOI: 10.29302/oeconomica.2017.19.2.2
} 
European directives are part of the secondary legislation issued by the European Parliament and calls on the Member States to achieve an objective, but without the need for a precise modality. Therefore, each Member State must comply with the Directive by transposing its provisions into national law in order to meet the expected objectives, having the need to report to the European Commission on the measures taken.

In Romania, the audit of the financial statements, both individual and consolidated, is regulated by normative acts, and until July 2017 it was regulated by Government Emergency Ordinance no. 75/1999 appointing financial audit activity, as subsequently amended and supplemented, Government Emergency Ordinance no. 90/2008 regarding statutory audit (with subsequent amendments and completions), the provisions of which foresee compliance with the European directives in the field. Starting July 2017, Romania's audit status is regulated by Law no. 162 from 6 July 2017 on statutory audit which also amends certain legal acts. In Romania, the professional body for coordinating, organizing and authorizing its audit and deployment is the Chamber of Financial Auditors of Romania (CAFR), which until the entry into force of Law 162/2017 was under the supervision of the Council for Public Activity Supervision Statutory Audit (CSPAAS).

The beginning of the activity in the field of audit in the Republic of Moldova, according to Veaceslav Ciobanu (2010), is with the approval of the Government Decision no. 648 of 19.11.1991, ie from the moment when the regulation regarding the audit service is approved for the first time and the first audit company Moldauditing SRL was created. Thus, Veaceslav Ciobanu (2010), in the electronic article "The Concept of Audit Development in the Republic of Moldova", states that during the same period of 1991, the creation of the Audit Chamber of the Republic of Moldova, whose functions consist, in licensing auditors, and developing audit policies to ensure audit quality.

The activity of this Chamber had a short duration of activity, which was abolished with the adoption of the Law on Audit Activity, which was proposed as of 15.02.1996, but accepted only on 24.03.2017. Veaceslav Ciobanu (2010) mentions in his research paper that this decision provided for the creation of an Association of all auditors - like CAFR in Romania - but which, however, failed to become an alternative to the Audit Chamber existing in the Republic of Moldova.

Unlike the fact that in Romania there is only one professional organization regarding the activity of the financial auditors (CAFR), in the Republic of Moldova we could identify three professional organization: the Association of Professional Accountants and Auditors of the Republic of Moldova (ACAP), the Association Auditors and Audit Societies of Moldova "AFAM" and the Association of Auditors and Management Consultants AO Ecofin-Consult (AACM).

According to the document entitled "The Concept on the Implementation of the Accounting Directive (2013/34 / EU) and the Audit Directive (2014/56 / EU)", adopted by the Ministry of Finance of the Republic of Moldova, it assumed a commitment to the European Union align with European audit legislation. Thus, from 1 September 2017, the Republic of Moldova should comply with the European Directives. In the context of audit legislation, a regime has been established requiring the designation of a single competent authority, currently the Ministry of Finance. Due to the fact that its functions include the administration of several domains at the same time, it is considered opportune to set up an Agency for Audit Activity Supervision (ASAA), as Ludmila Lapitskaia (2014) highlighted into her research paper.

In the paper "Practical Aspects of Implementation in Moldova of the Agreement on Association between the Republic of Moldova and the European Union related to the application of the Directive 2006/43 / EC", Lapitskaya et al. (2016) states that the Republic of Moldova has established a National Plan for Harmonization of Legislation to the European Directive 2006/43 / EC, modified by Directive 2014/56 / EU, which intends to adopt a Law starting 1 January 2018. In view of the mentioned by Lapitzkia et al. (2016) in its research, but also the fact that Romania (as a member state of the EU from 2007) could represent a good example for the Republic of Moldova regarding the practices of harmonization of the European legislation in the field of financial audit, 
we consider the research undertaken in this respect, and this study revealed in the dissemination of the comparative experiences of the two states. The aim is to highlight similarities and differences encountered into the transposition of Directive 2006/43/EEC, as amended by Directive 2013/56/EU into the two national legislations peered reviewed.

\section{Literature Review}

Any information in the fields of activity may be subject to an audit. (Loeb, et al., 1989).

In the United States, the first manuals on automated financial audit procedures appeared since 1961 and were written by Felix Kaufman (Electronic Data Processing and Auditing, 1961). Byrnes et al. (2012) presents, in their research, the evolution of the audit, from the traditional audit to the future audit.

In his paper, Power (1999, p. 1) describes the audit as an independent and systematic review of accounting and tax records, account statements and supporting documents in order to determine whether the entity under review has a true and fair view of its financial statements.

According to Porter (1997), one of the auditors' objectives is to detect fraud, and they are obliged to report any fraud found in the financial reports.

Owolabi et al (2016) analyzes the evolution and development of international audit, analyzing the historical and legislative background of the audit, and concluding that the past affects the present through the use of computerized audit systems (CAATs), and recommends that auditors try to define and understand their role.

Laptes et al. (2014) made a research regarding the evolution of the Romanian financial audit, presenting the main directions of development of the national financial audit until the time of the study, as well as perspectives for the future, concluding that there is an evolution over 2003 of the quality of the audit mission and it is necessary in the future to step up efforts to develop a system of quality assurance with regard to financial audit work. Salomia et al. (2014, p. 1) analyzes the impact of the implementation of the International Auditing Standards within the large entities located in Romania. The results of this research reveal that the application of ISAs was successfully applied by the companies surveyed, achieving positive results in terms of economic performance.

With the signing of the Association Agreement between the Republic of Moldova and the European Union in 2014, according to Anatolie Iachimovschi (2016), the Republic of Moldova commits itself to respect and at the same time to align the national legislation with the EU requirements in several fields, including in the field of financial audit. In this respect, Ludmila Lapitcaia (2016) states that the content of the Audit Law of the Republic of Moldova, published in 2007, was partly transposed the content of the Directive 2014/56 / EC, because some provisions of the law either fail to comply, or will be transposed in the near future, and the International Financial Auditing Standards will also be applicable. Ion Prisăcaru (2012) argues that what we are currently identifying according to the current legislation but also according to the activity of each auditor is that the regulation, supervision and licensing of the audit activity is within the competence of the state. From this point of view, we note that there is no authorized body empowered exclusively in the field, and the association of auditors and audit societies, according to Anatolie Iachimovschi (2016), is made exclusively for the pursuit of the interests of its members. Also, Iachimovschi argues that there is no interest for self-regulation of the financial audit activity at a national level.

\section{Research Methodology}

Given the importance of harmonizing national and European legislation, both of Romania (a country that has been a member of the European Union since 2007 and has to enforce laws in line with European directives) and of the Republic of Moldova (a European country outside the European Union zone but has accession aspirations), our study is based on a comparative analysis of the national legislations in audit matters developed by the two analyzed states in order to determine whether they are partially or totally harmonized with the European Directive on audit. 
The research is based on the hypothesis that Romania, as it is already a member of the EU, is obliged to harmonize the national legislation with the European Directive. The comparison is performed in order to determine convergences and divergences between national laws and the European Directive, with the main objective of comparing the European Directive with the Audit Law no. 61 XVI from 2007 which Republic of Moldova applies. Law no. 162, which Romania applies since 2017, is another argument for this analysis focused on the Law of the Republic of Moldova. The actuality of this law demonstrates the national interest in harmonizing legislation with the European Directives. We also want to identify the most important divergences between these laws in order to see whether the Republic of Moldova is in line with the requirements of the European Union.

The research method chosen for the present study is the comparative one, being important to identify theoretical elements of the concept of statutory audit in Romania and the Republic of Moldova in terms of transposing the European Directive regarding the audit activity into the national legislations. In this respect, we analyzed the extent to which the legislation on statutory audit in Romania and Republic of Moldova is in line with EU legislation by confronting the two national laws with the Directive. Specifically, we identified the three regulations that supported the comparative study (DE 2006/43/EC as amended by DE 2014/56/EU, Law No 162/2017 of Romania and Law No. 61 XVI of 2007 of the Republic of Moldova), the steps taken are directed at the punctual analysis of the requirements required by the European Directive. The aim is to observe and present whether or not national laws transposed these requirements. If the article has been transposed, a check mark is shown in Table 1. In the case of noncompliance of the requirements, the obligation for transposition into national law has been analyzed. We have also presented the most important divergences identified through our study with the help of Table 2 . Thus, on this basis, we have established the level of alignment with the requirements of the European Union of the two analyzed countries, focusing on the determination of the differences in Moldovan legislation. Interpretation of results can be found in the Results and Comments section.

\section{Results and Discussion}

The analysis of the three legislations has highlighted that Romania is harmonized with the demands of the European Union, although small language differences could also be identified, meaning that certain terms have been taken over and adapted to the national legislation and culture from a word terminology perspective. Some articles have also been transmuted entirely in national legislation, while others have been partially transposed or, on the contrary, complemented by national legislation. The results of the research were transposed in table no.1 as follows:

Table 1

Transposing the articles of the European Directive into national legislation

\begin{tabular}{|c|c|c|c|}
\hline \multicolumn{2}{|c|}{ European Union } & Romania & Republic of Moldova \\
\hline \multicolumn{2}{|c|}{$\begin{array}{c}\text { European Directive 2006/43/EC, as } \\
\text { amended by European Directive } \\
2014 / 56 / \mathrm{EU}\end{array}$} & $\begin{array}{l}\text { Law no. 162/2017 } \\
\text { regarding the "statutory } \\
\text { audit of the annual } \\
\text { financial statements and } \\
\text { consolidated annual } \\
\text { financial statements and } \\
\text { amending certain } \\
\text { normative acts" }\end{array}$ & $\begin{array}{c}\text { Law on Audit Activity } \\
\text { Nr. 61 XVI from } \\
\text { 16.03.2007 }\end{array}$ \\
\hline \multicolumn{4}{|c|}{ Chapter referring to definitions and main objective of the regulation } \\
\hline Article 1 & Main objective & & \\
\hline Article 2 & $\begin{array}{l}\text { Main definitions: } \\
\text { 1. Statutory audit }\end{array}$ & $\checkmark$ & - \\
\hline
\end{tabular}




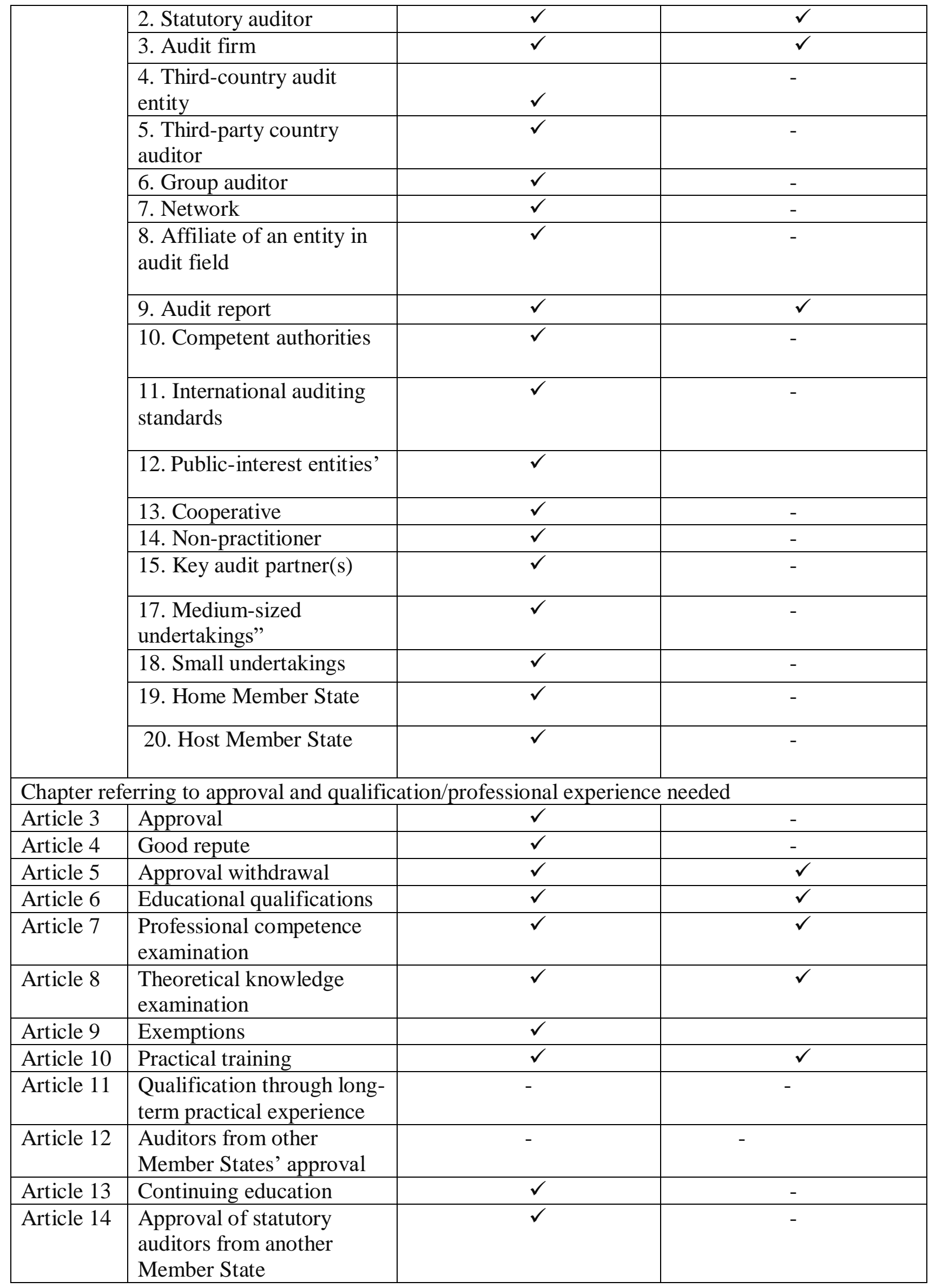




\begin{tabular}{|c|c|c|c|}
\hline \multicolumn{4}{|c|}{ Chapter referring to registration process } \\
\hline Article 15 & Public register & $\checkmark$ & $\checkmark$ \\
\hline Article 16 & $\begin{array}{l}\text { Registration of statutory } \\
\text { auditors }\end{array}$ & $\checkmark$ & $\checkmark$ \\
\hline Article 17 & Registration of audit firms & $\checkmark$ & $\checkmark$ \\
\hline Article 18 & $\begin{array}{l}\text { Updating of registration } \\
\text { information }\end{array}$ & $\checkmark$ & $\checkmark$ \\
\hline Article 19 & $\begin{array}{l}\text { Responsibility for } \\
\text { registration information }\end{array}$ & $\checkmark$ & $\checkmark$ \\
\hline Article 20 & Language & $\checkmark$ & $\checkmark$ \\
\hline \multicolumn{4}{|c|}{ Chapter referring to auditors' principles, professional ethics and audit fees } \\
\hline Article 21 & $\begin{array}{l}\text { Professional ethics and } \\
\text { scepticism }\end{array}$ & $\checkmark$ & - \\
\hline Article 22 & $\begin{array}{l}\text { I Independence and } \\
\text { objectivity }\end{array}$ & $\checkmark$ & $\checkmark$ \\
\hline Article 23 & $\begin{array}{l}\text { Confidentiality and } \\
\text { professional secrecy }\end{array}$ & $\checkmark$ & $\checkmark$ \\
\hline Article 24 & $\begin{array}{l}\text { Independence and } \\
\text { objectivity of individual } \\
\text { auditors from audit firms }\end{array}$ & $\checkmark$ & - \\
\hline Article 25 & Audit fees & $\checkmark$ & - \\
\hline \multicolumn{4}{|c|}{ Chapter referring to audit standards to be followed } \\
\hline Article 26 & Auditing standards & $\checkmark$ & $\checkmark$ \\
\hline Article 27 & $\begin{array}{l}\text { Statutory audits of } \\
\text { consolidated financial } \\
\text { statements }\end{array}$ & $\checkmark$ & - \\
\hline Article 28 & Audit reporting & $\checkmark$ & $\checkmark$ \\
\hline \multicolumn{4}{|c|}{ Chapter referring to quality assurance in audit } \\
\hline Article 29 & Quality assurance systems & $\checkmark$ & $\checkmark$ \\
\hline \multicolumn{4}{|c|}{ Chapter referring to sanctions } \\
\hline \multirow[t]{7}{*}{ Article 30} & $\begin{array}{l}\text { Systems of investigations } \\
\text { and sanctions }\end{array}$ & $\checkmark$ & - \\
\hline & 30a. Sanctioning powers & $\checkmark$ & - \\
\hline & $\begin{array}{l}\text { 30b. Application of } \\
\text { sanctions' effectiveness }\end{array}$ & $\checkmark$ & - \\
\hline & $\begin{array}{l}\text { 30c. Publications in matter } \\
\text { of sanctions and measures }\end{array}$ & $\checkmark$ & - \\
\hline & 30d. Appeal & $\checkmark$ & - \\
\hline & 30e. Reporting of breaches & $\checkmark$ & - \\
\hline & 30f. Information Exchange & $\checkmark$ & - \\
\hline Article 31 & Auditors' liability & $\checkmark$ & - \\
\hline \multicolumn{4}{|c|}{ Chapter referring to public oversight } \\
\hline Article 32 & $\begin{array}{l}\text { Principles of public } \\
\text { oversight }\end{array}$ & $\checkmark$ & - \\
\hline Article 33 & $\begin{array}{l}\text { Cooperation between } \\
\text { public oversight systems } \\
\text { within the European Union }\end{array}$ & $\checkmark$ & - \\
\hline Article 34 & Mutual recognition of & $\checkmark$ & - \\
\hline
\end{tabular}




\begin{tabular}{|c|c|c|c|}
\hline & $\begin{array}{l}\text { regulatory arrangements } \\
\text { between Member States }\end{array}$ & & \\
\hline Article 36 & $\begin{array}{l}\text { Professional secrecy and } \\
\text { regulatory cooperation }\end{array}$ & $\checkmark$ & - \\
\hline \multicolumn{4}{|c|}{ Chapter referring to the approval and dismissal of auditors } \\
\hline Article 37 & Appointment of auditors & $\checkmark$ & - \\
\hline Article 38 & $\begin{array}{l}\text { Dismissal and resignation } \\
\text { of auditors }\end{array}$ & $\checkmark$ & - \\
\hline \multicolumn{4}{|c|}{ Chapter referring to audit committee } \\
\hline Article 39 & Audit committee & $\checkmark$ & - \\
\hline \multicolumn{4}{|c|}{ Chapter referring to international aspects in matter of audit } \\
\hline Article 44 & $\begin{array}{l}\text { Approval of auditors from } \\
\text { third countries }\end{array}$ & $\checkmark$ & - \\
\hline Article 45 & $\begin{array}{l}\text { Registration and oversight } \\
\text { of third-party countries' } \\
\text { auditors }\end{array}$ & $\checkmark$ & - \\
\hline Article 46 & $\begin{array}{l}\text { Derogation in the case of } \\
\text { equivalence }\end{array}$ & $\checkmark$ & - \\
\hline Article 47 & $\begin{array}{l}\text { Cooperation between } \\
\text { competent authorities }\end{array}$ & $\checkmark$ & - \\
\hline \multicolumn{4}{|c|}{ Chapter referring to final provisions } \\
\hline Article 48 & Committee procedure & $\begin{array}{l}\text { Power of the European } \\
\text { Commission }\end{array}$ & $\begin{array}{c}\text { Power of the European } \\
\text { Commission }\end{array}$ \\
\hline
\end{tabular}

Source: Authors' research on the three analyzed regulations based on EU's requirements found in Directive's articles

As can be seen from table no.1, Romania complies with and transposes into national legislation the requirements of the European Directive. Initially, the European Directive 2006/43/EC consisted of 49 articles. Following the change introduced with the entry into force of Directive 2014/56/EU, Directive 2006/43/EC amounts a total of 43 articles. In Romania, 40 articles were transposed by Law no. 162/2017, two articles are not binding, and one (Article 48) is addressed to the European Commission. Instead, the Republic of Moldova, through Law no. 61 XVI of 2007, transposed a number of only 17 articles. Article 2, on definitions, has been partly incorporated into national law. Of non-transposed articles, only three are optional. In other words, the Republic of Moldova has transposed the European Directive into national legislation in a proportion of less than $43 \%$, meaning a relatively low compliance rate with European legislation. However, we can argue that the non-EU state is making efforts to harmonize national legislation with the European regulations.

We find that the transposition into national legislation of 17 articles and three definitions under Article 2 could be identified as convergence between the three regulations analyzed. These convergences can be seen in Table 1 on the lines of the table in which they simultaneously ticked the columns related to Law no. 162/2017 and Law 61 XVI of 2007, which correspond to the column of the European Directives.

Following the analysis, divergences could also be identified regarding the transposition into the legislation of Romania and the Republic of Moldova of the European Directive. Some of these identified divergences are presented schematically in table no.2: 
Table 2

The main divergences identified between the national legislation under consideration and the European Directives

\begin{tabular}{|c|c|c|}
\hline European Union & Romania & Republic of Moldova \\
\hline $\begin{array}{c}\text { European Directive } \\
\text { 2006/43/EC, as amended by } \\
\text { European Directive } \\
\text { 2014/56/EU }\end{array}$ & $\begin{array}{l}\text { Law no. 162/2017 regarding } \\
\text { the statutory audit of the } \\
\text { annual financial statements } \\
\text { and consolidated annual } \\
\text { financial statements and } \\
\text { amending certain normative } \\
\text { acts }\end{array}$ & $\begin{array}{c}\text { Law on Audit Activity Nr. } 61 \\
\text { XVI from 16.03.2007 }\end{array}$ \\
\hline „Legal audit” term is used & „Statutary audit” term is used & „Audit” term is used \\
\hline $\begin{array}{l}\text { Member States shall each } \\
\text { appoint their respective } \\
\text { competent authorities. }\end{array}$ & $\begin{array}{l}\text { One competent authority, } \\
\text { independent of the Ministry of } \\
\text { Finance: ASPAAS. }\end{array}$ & $\begin{array}{l}\text { Competent Authorities: } \\
\text { Licensing Chamber and } \\
\text { Ministry of Finance. }\end{array}$ \\
\hline $\begin{array}{l}\text { Auditors and/or audit firm must } \\
\text { maintain } \\
\text { skepticism and respect the } \\
\text { principles of professional } \\
\text { ethics. }\end{array}$ & $\begin{array}{l}\text { This mention is also included } \\
\text { in this law. }\end{array}$ & $\begin{array}{l}\text { "Professional skepticism" term } \\
\text { is not specified, but only the } \\
\text { requirement that auditors are } \\
\text { obliged to respect the principles } \\
\text { of professional ethics. }\end{array}$ \\
\hline $\begin{array}{l}\text { The term „Good reputation” is } \\
\text { mentioned. }\end{array}$ & $\begin{array}{l}\text { This Article is mentioned into } \\
\text { the law. }\end{array}$ & $\begin{array}{l}\text { "Good Reputation" term is not } \\
\text { metioned into the law. }\end{array}$ \\
\hline $\begin{array}{l}\text { Chapter VII states that, where } \\
\text { sanctions already exist in the } \\
\text { content of internal criminal } \\
\text { law, Member States are not } \\
\text { required to frame rules on them } \\
\text { within the competent authority. }\end{array}$ & $\begin{array}{l}\text { It is necessary to develop } \\
\text { sanctioning rules by ASPAAS, } \\
\text { even if they are contained in } \\
\text { the content of internal criminal } \\
\text { law. }\end{array}$ & $\begin{array}{l}\text { This mention is not transposed } \\
\text { into the national law. }\end{array}$ \\
\hline
\end{tabular}

Source: Authors' research on the three analyzed regulations

\section{Conclusion}

The transposing process of EU Regulation 537/2014 and of Directive 2014/56/EU into national legislation is a priority process in both Romania and the Republic of Moldova, with amendments to national audit laws being implemented in order to create an appropriate framework for audit missions in order to lead to a more transparent and competitive business environment at European and international level.

By interpreting the results obtained, we can conclude that in Romania exists a greater effort to harmonize the legislation on the statutory audit with the requirements of the European Union, compared to the Republic of Moldova, which has a slower pace of convergence with the European Directives. However, we can note that the efforts made by the Republic of Moldova to comply with the European requirements are observed in view of the fact that almost half of the requirements of the European Directives in audit matter have been transposed into the national legislation.

The convergences identified in the legislation under review show us that both countries are taking measures to comply with the European Directive, these laws having similarities in form and substance resulting from their adaptation to the requirements of the European Union. However, the identified divergences decrease the degree of compliance of these laws with the European Directive, indicating that there are still provisions in the Directive that are not adopted by at least one of the two countries under consideration, or these provisions are not fully adopted. 
We believe that the differences found may result from the different views of the States concerned on the interpretation of the Directive (given that the European Union does not provide a well-defined transposition path, leaving each Member State to adopt its own conformity measures). These differences may also derive from the needs of the countries under consideration, adaptation to the business, cultural, political environment, etc. This study opens up new research directions, of which interest in the future would be the identification and critical analysis of the causes for which there are differences between the transposition of the European Directive in Romania and the transposition of the European Directive into the Republic of Moldova, as well as the practical effects regarding the transparency and credibility of the financial information.

\section{References}

1. Brynes, P.E., Al-Awadhi, A., Gullvist, B., Brown-Liburd, H., Teeter, R., Warren, J. D., Vasarhelyi, M., Evolution of Auditing: From the Traditional Approach to the Future Audit, AICPA, White Paper, 2012, https://www.aicpa.org/interestareas/frc/assuranceadvisoryservices/downloadabledocuments/ whitepaper_evolution-of-auditing.pdf.

2. Ciobanu, V., 2010, Concept privind dezvoltarea auditului în Republica Moldova, Revista electronică contabilsef.md.

3. Directive 2014/56/EU of the European Parliament and of the Council Of The European Union of 16 April 2014 amending Directive 2006/43/EC on Statutory Audits of Annual Accounts and Consolidated Accounts, Official Journal of the European Union, L 158/196.

4. Directive 2006/43/EC of the European Parliament and of the Council Of The European Union of 17 May 2006 on statutory audits of annual accounts and consolidated accounts, amending Council Directives 78/660/EEC and 83/349/EEC and repealing Council Directive 84/253/EEC, Official Journal of the European Union, L 157/87.

5. FAC 2001, Code of Ethics for Professional Accountants, IFAC Ethics Committee, New York, NY.

6. IAASB, 2015. Handbook of International, Quality Control, Auditing, Review, Other Assurance, and Related Services Pronouncements, Volume I, ISBN 978-1-60815-250-6.

7. Iachimovschi, A., 2016, Aspecte privind racordarea la bunele practici internaţionale de asigurare a calităţii auditului financiar, Conferința științifică internațională consacrată celei de-a XXV-a aniversări ASEM, Chișinău, Volumul IV, Ed. ASEM, p. 207, ISBN 978-997575-838-3.

8. Kaufman, F., Electronic Data Processing and Auditing, The Ronald Press Company; First Edition, Later Printing edition (1961).

9. Knechel, W.R., Krisnan, G.V, Pevzner, M., Shefchik, L., Velury, U., 2012. Audit Quality: Insights from the Academic Literature, Auditing A Journal of Practice \& Theory.

10. Lapițcaia, L., Основные требования, предъявляемые международными стандартами аудита к аудиторской документации, Conferința științifică internațională consacrată celei de-a XXV-a aniversări ASEM, Chișinău, Volumul IV, 2016, Ed. ASEM

11. Lapițkaia, L., Leahovcenco, A., Aspectele practice de implementare în Moldova a prevederilor Acordului de asociere între Republica Moldova și Uniunea Europeană aferente aplicării Directivei 2006/43/CE, EUREM 2016 Conference Proceedings, Chișinău, 2016, p. 167, https://mruni.pure.elsevier.com/ws/portalfiles/portal/8483542.

12. Laptes, R., Popa, A., F., Dobre, F., 2014, Research on the Evolution of Financial Audit in Romania - Past, Current and Future Trends, Procedia Economics and Finance, p. 807 - 814, https://ac.els-cdn.com/S2212567114005231/1-s2.0-S2212567114005231-

main.pdf?_tid=0d491bb8-c6d5-11e7-bae1-

00000aab0f26\&acdnat=1510400581_e66582c5b335d8622874095126091e13. 
13. Law no. 61 regarding the audit activity, dated March 16, 2007, published in the Official Gazette no. 117-126, Republic of Moldova.

14. Law no. 162 on the Statutory Audit of the Annual Financial Statements and the Consolidated Annual Financial Statements and Amending Some Normative Acts of July 6, 2017, Romanian Parlament, published in the Official Gazette no. 548 of 12 July 2017.

15. Loeb, S. E.; Shamoo, A. E., 1989, Data audit: Its place in auditing, Accountability in Research. 1 (1): 23-32. ISSN 0898-9621. PMID 26859053.

16. Manoli, M., 2016, Reflecţii privind calitatea lucrărilor de audit, Conferința științifică internațională consacrată celei de-a XXV-a aniversări ASEM, Chișinău, Volumul IV, Ed. ASEM, pag, 72.

17. The Ministry of Finance of the Republic of Moldova, the Concept on the Transposition of the Accounting Directive (2013/34/EC) and the Audit Directive (2014/56/EU), 2015, Chisinau.

18. Owolabi, S., A., Jayeoba, O., O, Ajibade, A., T., 2016, Evolution and development of auditing, Unique Journal of Business Management Research Vol. 3(1), pp. 032-040, April, 2016.

19. Porter, B., Auditors' Responsibilities with Respect to Corporate Fraud-A Controversial Issue, Current Issues in Auditing: SAGE Publications, 1997.

20. Power, M., The Audit Society - Rituals of Verification, Oxford, 1997, ISBN-13: 9780198296034.

21. Prisăcaru, I., Proceduri și particularități de auditare a situațiilor financiare întocmite conform SIRF, Martie 2012, Revista Contabilitate și Audit Nr.3, Ed. Publicație periodică Contabilitate Și audit SRL.

22. Salomia, M., M., Turlea, E., Dobre, F., 2014, Study of Financial Audit Used in Large Companies in Romania in the Context of the Implementation of Auditing Standards Harmonized with International Audit Standards, Procedia - Social and Behavioral Sciences, Volume 109, 8 January 2014, Pages 995-997, https://ac.elscdn.com/S1877042813052166/1-s2.0-S1877042813052166-main.pdf?_tid=d03a06f6-c6d411e7-9153-00000aacb361\&acdnat=1510400478_badb6e16e6f13ac274c0622a0622330c.

23. Șelaru, M., Șchendra, A., Aspiraţii europene ale profesiei de audit din Republica Moldova: situaţia curentă a procesului de armonizare şi transpunere a Directivelor Europene, Practici de Audit Financiar, Anul V, Nr. 2(18)/2016, p. 48, https://www.cafr.ro/uploads/Revista_pa_nr_2_2016-d936.pdf .

24. Schoderbek, M., Bamber, L., Bamber, E.M., 1993. Audit Structure and Other Determinants of Audit Report Lag: An Emprical Analysis. Auditing: A Journal of Practice and Theory, $12,1,1-23$. 